\title{
GNAS NP_000507.1:p.R201H
}

National Cancer Institute

\section{Source}

National Cancer Institute. GNAS NP 000507.1:p.R201H. NCI Thesaurus. Code C146958.

A change in the amino acid residue at position 201 in the guanine nucleotide-binding protein $\mathrm{G}(\mathrm{s})$ subunit alpha isoforms short protein where arg inine has been replaced by histidine. 